\title{
Effects of Probiotic Bacteria on Candida Presence and IgAAnti-Candida in the Oral Cavity of Elderly
}

\author{
Fabio Henrique Boarini Pacheco MENDONÇA ${ }^{1}$ \\ Silvana Soléo Ferreira dos SANTOS ${ }^{1}$ \\ Ivan da Silva de FARIA ${ }^{1}$ \\ Célia Regina GONÇALVES e SILVA ${ }^{1}$ \\ Antônio Olavo Cardoso JORGE ${ }^{2}$ \\ Mariella Vieira Pereira LEÃO ${ }^{1}$ \\ ${ }^{1}$ Basic Institute of Biosciences, UNITAU - University of Taubaté, Taubaté, SP, Brazil \\ ${ }^{2}$ São José dos Campos Dental School, UNESP - Univ Estadual Paulista, São José dos Campos, SP, Brazil
}

\begin{abstract}
Imbalance in the resident microbiota may promote the growth of opportunistic microorganisms, such as yeasts of Candida genus and the development of diseases, especially in aged people. This study evaluated whether the consumption of the probiotic Yakult LB ${ }^{\circledR}$ (Lactobacillus casei and Bifidobacterium breve) was able to influence on the specific immunological response against Candida and on the presence of these yeasts in the oral cavity of 42 healthy aged individuals. Saliva samples were collected before and after the probiotic use for 30 days, 3 times a week. The samples were plated in Dextrose Saboraud Agar with chloramphenicol, the colonyforming units $(\mathrm{CFU} / \mathrm{mL})$ were counted and the Candida species were identified. Anti-Candida IgA analysis was conducted using the ELISA technique. ANOVA and Student's t-test were used for normally distributed data and the Wilcoxon test was used for data with non-normal distribution $(\alpha=0.05)$. The results showed a statistically significant reduction $(\mathrm{p}<0.05)$ in Candida prevalence (from $92.9 \%$ to $85.7 \%$ ), in CFU/mL counts of Candida and in the number of non-albicans species after consumption of the probiotic. Immunological analysis demonstrated a significant increase $(\mathrm{p}<0.05)$ in anti-Candida IgA levels. In conclusion, probiotic bacteria reduced Candida numbers in the oral cavity of the elderly and increased specific secretory immune response against these yeasts, suggesting its possible use in controlling oral candidosis.
\end{abstract}

Key Words: Candida, probiotics, geriatrics, elderly.

\section{INTRODUCTION}

Yeasts of Candida genus are normal constituents of the human flora, found as commensal on skin, genitourinary and gastrointestinal tracts (1). These microorganisms can be isolated in the oral cavity of $20 \%$ to $80 \%$ of healthy individuals $(2,3)$. However, some factors, such as immunosuppression and use of broadspectrum antimicrobial drugs, can favor their overgrowth and the development of candidosis (4). Oral candidosis is a common problem among the elderly, denture wearers are more susceptible to the disease $(5,6)$.

Products known as probiotics have been consumed for many years for therapeutic and prophylactic reasons. The presence of probiotic microorganisms in mucosa can prevent the growth of other bacterial species by production of acid and antimicrobial products (7) or by interference on the mucosa immunity by modulating IgA synthesis and mucus production (8).

Experiments performed with probiotic bacteria, Lactobacillus acidophilus and Lactobacillus fermentum in rats infected with Candida albicans showed a significant reduction in amounts of yeasts in the oral cavity, suggesting a therapeutic capacity of these bacteria in candidosis (9).

Hatakka et al. (10) also observed a reduction of $32 \%$ on Candida prevalence in the oral cavity of elderly who consumed a cheese enriched with probiotic bacteria.

With the increase in life expectancy, geriatric problems became more frequent. Being candidosis a common disease among the elderly, the search for products that could help in its treatment is important 
Therefore, the aim of this study was investigate the effect of Yakult LB ${ }^{\circledR}$ consumption in Candida spp. presence and in anti-Candida IgA levels in the oral cavity of elderly.

\section{MATERIAL AND METHODS}

\section{Studied Population}

After approval of the research project by the institutional Ethics Committee (Protocol \#057/08), 42 institutionalized women aged 65 or older who lived in the city of Taubaté, SP, Brazil, were clinically healthy and had not used antibiotics or immunossupressors for the previous 3 months were selected for the study. The sample size was determined considering: the total number of clinically healthy aged women of the institutions ( $\mathrm{n}=50$ ), $5 \%$ of error, $95 \%$ of confidence level and $80 \%$ of expected prevalence of Candida based on previous pilot study. Preliminary analyses regarding the oral and dental conditions were performed, including presence of periodontal disease, periodontal pockets and mucosal lesions. When these lesions were detected, the patients were included in the study and treated only after enrolment to avoid interference in the results. Patients with emergency conditions were not included and were treated immediately. If any new fact that could influence the results (e.g.: antibiotics use) emerged during the course of the study, the samples of that patient were also excluded. All participants and their caregivers were fully informed about the objectives and methodology of the study and signed an informed consent form.

\section{Saliva Samples and Probiotic consumption}

Samples of volunteers' saliva were collected without stimulation, about $2 \mathrm{~h}$ after oral hygiene, in the morning or in the afternoon, depending on the rules designated by the institution. The samples were stored in sterile disposable collectors and kept on ice up to $3 \mathrm{~h}$. Then, a fraction of the samples was plated in culture media for isolation and identification of Candida yeasts. Another fraction was kept in a vial added of phenylmethylsulfonyl fluoride $0.1 \mathrm{mM}$ (Sigma Co., St Louis, MO, USA) and sodium azide $0.1 \%$ (Difco Laboratories Inc., Detroit, MI, USA) at $-20^{\circ} \mathrm{C}$, for assessment of IgA levels.

The caregivers were instructed to mix $1 \mathrm{~g}$ (content of 1 envelope) of the probiotic Yakult LB ${ }^{\circledR}$ (Yakult S/A Industria e Comércio, Caçapava, Brazil) (Lactobacillus casei and Bifidobacterium breve, $2 \times 10^{7}$ to $10^{9}$ and $5 \times 10^{7}$ to $10^{9} \mathrm{CFU} / \mathrm{mL}$, respectively) with some kind of juice and give to the elderly 3 times a week, at the same hour, for 30 days. After this period, another saliva sample was collected from each participant.

\section{Isolation, Counting and Identification of Candida Genus}

The original samples or samples diluted 10-fold serially were plated in duplicate in Saboraud Dextrose Agar(Oxoid, Lawrence, KS, USA) with chloramphenicol $(1 \mathrm{mg} / \mathrm{mL})$ (Inlab, São Paulo, SP, Brazil) and incubated at $37^{\circ} \mathrm{C}$ for $48 \mathrm{~h}$ at room temperature for 5 days. The number of colony forming units per $\mathrm{mL}$ of saliva $(\mathrm{CFU} / \mathrm{mL})$ was counted. Suggestive colonies from each plate were confirmed by smear tests stained by the Gram technique. The Candida species were identified by phenotypic (germinative tube formation and chlamydoconidia production) and biochemistry tests (fermentation and assimilation of carbohydrates and urase test).

\section{$\lg A$ Analyses}

The levels of anti-Candida IgA were also analyzed using the ELISA technique. Sensitization of ELISA plates was performed using surface antigens from Candida cells, prepared as described by Koga-Ito et al. (11). The plates were then incubated with diluted saliva (1:10), followed by an anti-human IgA labeled with horseradish peroxidase. The reaction was developed with orthophenylenediamine and $\mathrm{H}_{2} \mathrm{O}_{2}$ as substrate. Absorbance was measured at $450 \mathrm{~nm}$.

\section{Statistical Analysis}

First, the normality of the data $(\mathrm{CFU} / \mathrm{mL}$ counts and IgA anti-Candida levels, before and after the use of probiotics) was evaluated using the D'Agostino test. ANOVA and Student's t-test were used for normally distributed data while the Wilcoxon test was used for data with non-normal distribution. A significance level of 5\% was established for all analyses.

\section{RESULTS}

The results showed a reduction in the prevalence of Candida in oral cavity of elderly, since 39 (92.9\%) individuals carried the microorganism before probiotic 
consumption and after that just $36(85.7 \%)$. A statistically significant reduction in $\mathrm{CFU} / \mathrm{mL}$ counts $(\mathrm{p}=0.02$, Wilcoxon test) and in the $\log$ of CFU $/ \mathrm{mL}$ counts (Fig. 1) $(p=0.0$, ANOVA test; $p=0.03$, Student's t-test) was also observed. There was a reduction in Candida numbers in $57.1 \%$ of the elderly and total elimination of the yeasts in $11.9 \%$ of them.

Among the identified species, C. albicans was the most frequently isolated one before and after the probiotics use. The species profile was slightly modified, since a reduction in the numbers of non-albicans species was observed (Table 1).

Table 1. Candida species identified from oral cavity of elderly individuals before and after probiotics use.

\begin{tabular}{lcccccc}
\hline \multirow{2}{*}{ Specie } & \multicolumn{2}{c}{ Before } & & \multicolumn{2}{c}{ After } \\
\cline { 2 - 3 } \cline { 6 - 6 } \cline { 5 - 6 } C. albicans & 28 & 57.1 & & 25 & 69.4 \\
C. tropicalis & 8 & 16.3 & & 5 & 13.9 \\
C. guilliermondii & 6 & 12.2 & & 3 & 8.3 \\
C. glabrata & 3 & 6.1 & & 2 & 5.6 \\
C. lipolytica & 1 & 2.0 & & - & - \\
C. krusei & 1 & 2.0 & & 1 & 2.8 \\
C. kefyr & 1 & 2.0 & & - & - \\
C. parapsilosis & 1 & 2.0 & & - & - \\
Total & 49 & 100 & & 36 & 100 \\
\hline
\end{tabular}

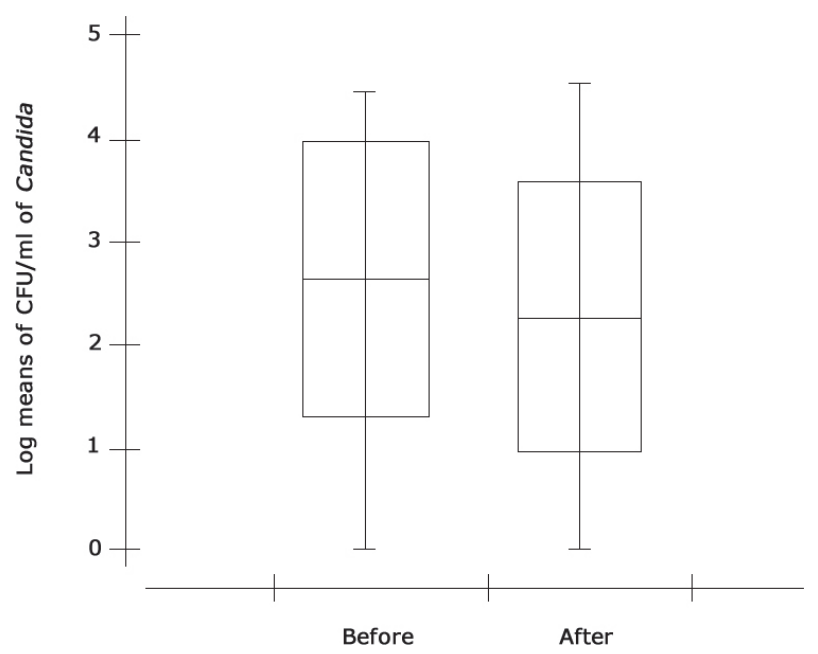

Figure 1. Log means of CFU/mL of Candida from the oral cavity of elderly before and after use of probiotics $(\mathrm{p}=0.0$, ANOVA test; $\mathrm{p}=0.03$, Student's t-test).
Immunological analysis showed a significant increase in the levels of anti-Candida $\operatorname{IgA}(\mathrm{p}=0.00$, ANOVA test and $\mathrm{p}=0.01$, Student's t-test) (Fig. 2). The results showed that $26(61.9 \%)$ individuals had their IgA levels increased, and from them 17 (65.4\%) had a reduction in amounts of Candida in the oral cavity.

\section{DISCUSSION}

With the increase in life expectation, works involving geriatrics are becoming more and more important. Being the aged population more susceptible to Candida colonization, it was expected to find a high prevalence of the fungus in the oral cavity of the studied individuals. Nevertheless, the results showed a reduction in the prevalence and counts of Candida after probiotic use. Santos et al. (12) had already observed a similar effect with the same product (Yakult LB ${ }^{\circledR}$ ), but in a younger population. Hatakka et al. (10), also studying elderly, observed a decrease from $30 \%$ to $21 \%$ in the prevalence of Candida in oral cavity after the consumption of a cheese enriched with probiotic bacteria. Although Candida presence could be influenced by many factors, it is important to highlight that the older people of the present study maintained the same habits and were accompanied throughout the experiment by the caregivers of the institution, who administered the probiotic in a blind manner, i.e., without knowledge of the elderly. With this, the placebo effect was minimized, a study with a placebo group would be appropriate. The

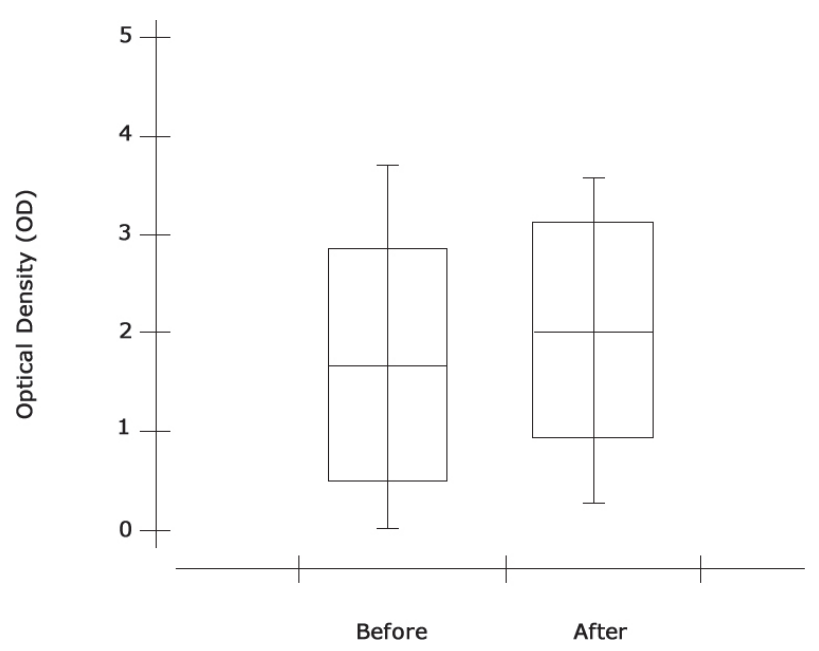

Figure 2. Optical density (OD) corresponding to IgA anti-Candida levels of the oral cavity of elderly individuals before and after use of probiotics ( $\mathrm{p}=0.0$, ANOVA test; $\mathrm{p}=0.01$, Student's t-test). 
quality of the samples could also contribute to variations. However, in the whole experiment, it was maintained the same time for the collection of the samples and the maximum of $3 \mathrm{~h}$ for processing them, reducing the risk of interferences.

The identification of analyses showed that $C$. albicans was the most prevalent species before and after the probiotic use. Its predominance in the oral cavity has been demonstrated $(6,12,13)$. Several non-albicans species were also isolated, a phenomenon identified in long-term antibiotic users, immunossupressed and chronic pathologies patients (14-16). For example, Alberth et al. (15) observed the substitution of C. albicans for non-albicans species (C. kefyr, C. lusitaniae, $C$. sake, $C$. tropicalis) in children with cancer, especially in the stages of severe neutropenia. Costa et al. (16) observed an increase in non-albicans species in HIVinfected patients, although C. albicans was still the most frequent. Thus, the elderly of this work had a profile of Candida species more similar to patients with a predisposing factor. However, with the probiotic use there was a reduction in non-albicans species frequency, approximating the elderly to a healthy profile.

Controversial results regarding the role of secretory antibodies in the prevention of Candida infections and the correlation of Candida and antiCandida IgA levels have been reported. Silva et al. (17) observed that patients with vaginal candidiasis showed lower levels of anti-Candida IgA in saliva when compared with the control group (absence of candidosis). In contrast, Kantardjiev and Popova (18) reported that the saliva samples of patients with denture stomatitis, mainly associated with Candida, showed higher titers of anti-Candida antibodies.

The present results revealed that after the period of probiotics use, a significant increase in the levels of specific IgA was observed. According to Boirivant and Strober (19), probiotics can improve the defense function of epithelial cells by the induction of cytokine secretion and the production of immunoglobulins and antimicrobial substances. Since some individuals in this study did not present the yeast or showed diminished amounts in the oral cavity after probiotics use, it is likely that Candida elimination could have occurred due to secretory immunological stimulation.

The maintenance and re-establishment of the internal balance, frequently compromised in older people, are the best alternative to avoid the development of candidosis and other opportunistic diseases.
The findings of this study suggest that the periodic consumption of probiotics could help recovering this equilibrium and eliminating less adherent Candida species, but with pathogenic potential.

\section{RESUMO}

Desequilíbrios na microbiota residente podem promover o crescimento de microrganismos oportunistas, como as leveduras do gênero Candida, e o desenvolvimento de doenças, especialmente na população idosa. Este estudo investigou se o consumo do probiótico Yakult LB $^{\circledR}$ (Lactobacillus casei e Bifidobacterium breve) era capaz de influenciar na resposta imune secretória anti-Candida e na presença destes microrganismos na cavidade bucal de 42 idosas saudáveis. Amostras de saliva foram coletadas antes e depois do consumo do probiótico por 30 dias, 3 vezes por semana. As amostras foram semeadas em Agar Saboraud Dextrose com cloranfenicol, as unidades formadoras de colônias (UFC/mL) foram contadas e as espécies de Candida foram identificadas. A análise de IgA anti-Candida foi realizada pela técnica ELISA. Os resultados demonstraram redução na prevalência de Candida (de $92,9 \%$ para $85,7 \%$ ), na contagem de UFC/mL $(\mathrm{p} \leq 0,05)$ e no número de espécies não-albicans, depois do consumo do probiótico. As análises imunológicas mostraram um aumento significativo dos níveis de IgA antiCandida $(\mathrm{p} \leq 0,05)$. Concluindo, as bactérias probióticas reduziram significantemente a quantidade de Candida na cavidade bucal dos idosos e aumentaram a resposta imune secretória específica para esta levedura, sugerindo a possibilidade de sua utilização no controle da candidose bucal.

\section{ACKNOWLEDGEMENTS}

The authors thank Yakult S/A Indústria e Comércio (Caçapava, SP, Brazil) for the donation of Yakult $\mathrm{LB}^{\circledR}$ samples.

\section{REFERENCES}

1. Miranda LN, van der Heijden IM, Costa SF, Sousa AP, Sienra RA, Gobara S, et al.. Candida colonization as a source for Candidaemia. J Hosp Infect 2009;72:9-16.

2. Oksuz S, Sahin I, Yildirim M, Gulcan A, Yavuz T, Kaya D, et al.. Phospholipase and proteinase activities in different Candida species isolated from anatomically distinct sites of healthy adults. Jpn J Infect Dis 2007:60:280-283.

3. Tsang CS, Chu FC, Leung WK, Jin LJ, Samaranayake LP, Siu SC. Phospholipase, proteinase and haemolytic activities of Candida albicans isolated from oral cavities of patients with type 2 diabetes mellitus. J Med Microbiol 2007;56:1393-1398.

4. Vecchiarelli A, Pericolini E, Gabrielli E, Pietrella D. New approaches in the development of a vaccine for mucosal candidiasis: progress and challenges. Front Microbiol 2012;3:1-7.

5. Pinto TMS, Neves ACC, Leão MVP, Jorge AOC. Vinegar as an antimicrobial agent for control of Candida spp. in complete denture wearers. J Appl Oral Sci 2008;16:385-390.

6. Pires F, Santos E, Bonan P, De Almeida O, Lopes M. Denture stomatitis and salivary Candida in Brazilian edentulous patients. J Oral Rehabil 2002;29:1115-1119.

7. Sobel JD. Vulvovaginal candidosis. Lancet 2007;369:1961-1971. 
8. Matsuzaki T, Takagi A, Ikimura H, Matsuguchi T, Yokokura T. Intestinal microflora: probiotics and autoimmunity. J Nutr 2007;137:798S-802S.

9. Elahi S, Pang G, Ashman R, Clancy R. Enhanced clearance of Candida albicans from the oral cavities of mice following oral administration of Lactobacillus acidophilus. Clin Exp Immunol 2005;141:29-36.

10. Hatakka K, Ahola AJ, Yli-knuuttila H, Richardson M, Poussa T, Meurman JH, et al.. Probiotics reduce the prevalence of oral Candida in the elderly - a randomized controlled trial J Dent Res 2007;86:125-130.

11. Koga-Ito CY, Unterkircher CS, Watanabe H, Martins CA, Vidotto V, Jorge AO, et al.. Caries risk tests and salivary levels of immunoglobulins to Streptococcus mutans and Candida albicans in mouthbreathing syndrome patients. Caries Res 2003;37:38-43.

12. Santos AL, Jorge AOC, Santos SSF, Silva CRG, Leão MVP. Influence of probiotics on Candida presence and IgA anti-Candida in the oral cavity. Braz J Microbiol 2009;40:960-964.

13. Weckwerth PH, Carnietto C, Weckwerth AC, Duarte MA, Kuga $\mathrm{MC}$, Vivan RR. In vitro susceptibility of oral Candida albicans strains to different $\mathrm{pH}$ levels and calcium hydroxide saturated aqueous solution. Braz Dent J 2012;23:192-198.

14. Querido SMR, Back-Brito GN, Santos SSF, Leão MVP, KogaIto CY, Jorge AOC. Opportunistic microorganisms in patients undergoing antibiotic therapy for pulmonary tuberculosis. Braz $\mathrm{J}$ Microbiol 2011;42:1321-1328.

15. Alberth M, Majoros L, Kovalecz G, Borbás E, Szegedi I, J Márton I, et al.. Significance of oral Candida infections in children with cancer. Pathol Oncol Res 2006;12:237-241.

16. Costa CR, de Lemos JA, Passos XS, de Araújo CR, Cohen AJ, Souza LK, et al.. Species distribution and antifungal susceptibility profile of oral Candida isolates from HIV-infected patients in the antiretroviral therapy era. Mycopathol 2006;162:45-55.

17. Silva CRG, Melo KE, Leão MVP, Ruis R, Jorge AOC. Relationship between Candida in vaginal and oral mucosae and salivary IgA. Rev Bras Ginecol Obstet 2008;30:300-305.

18. Kantardjiev TV, Popova EV. Anti-Candida antibodies in serum and saliva of patients with denture stomatitis. Folia Med (Plovdiv) 2002;44:39-44.

19. Boirivant M, Strober W. The mechanism of action of probiotics. Curr Opin Gastroenterol 2007;23:679-692. 